\title{
ABSTRACTS OF A.A.P.G.-S.E.P.M.-M.S.E.G. PAPERS
}

\author{
Holston, Texas, March 25-28, 1963
}

ANDERSON, ROGER Y., Department of Geology, University of New Mexico

Influence of Climate on Varves and Bedding

Varved sediments provide an imperfect record of changes in climate by means of variations in varve thickness. Erratic varve thickness pulsations with about 2 to 30 years between maxima agree with similar fluctuations in meteorologic records and show no strong periodicities according to power spectrum studies. However, weak rapidly changing climatic patterns are generally present with a slight favoritism for periodicities near 5 years.

Normally, varves form in quiet places that are relatively insensitive to the short climatic oscillations, but three sequences (Devonian Beaverhill Lake Formation, Oligocene Florissant lake beds, Miocene Monterey Formation) have yielded some information about them and about certain aspects of bedding. The short-term changes ( 2 to 30 years) are at least partially responsible for the timing of severe storms and floods that scour the bot tom or shed coarse clastic layers into a basin.

Subtle varve thickness trends with a tendency toward quasiperiodicity near 90 and 180 years that may be related to solar activity have been observed, and varve calibration of bedding features formed in quiet lowenergy situations suggests that low energy (Fondo) bedding couplets on the scale of $1 \mathrm{~cm}$ to $3 \mathrm{dcm}$ are the result of 100-300-year climatic changes. Bedding features of the same and larger scale formed in higher energy environments are under the influence of the shorter, more erratically timed, climatic fluctuations.

ANTOINE, JOHN $W$, AND HARDING, JAMES, Agricultural and Mechanical College of Texas, College Station, Texas

Structure of Portions of the Northern Continental Shelf, Gulf of Mexico, as Determined by Seismic Refraction Measurements

The data from numerous seismic refraction profiles are presented in the form of five cross sections and three isopach maps. The specific areas covered are (1) the continental shelf south of Galveston, Texas, and (2) the continental shelf south of the Florida Panbandle. The area south of Galveston is represented by one cross section. This section shows the continuation seaward of the south-dipping sedimentary beds of the Texas Gulf Coast to a point approximately $60 \mathrm{~km}$. south of Galveston where a reversal of dip is noted. At this point, presumably the axis of the Gulf Coast geosyncline, there are $13 \mathrm{~km}$. of post-Cretaceous sediments. A broad ridge between the geosyncline and the Sigsbee scarp is shown. In the area south of the Florida Panhandle, four cross sections and three isopach maps show the relationship between the known onshore structure and the structure of the shelf. A continuation seaward of the Apalachicola embayment is noted and the great thickening of the Lower Cretaceous is shown to continue approximately $20 \mathrm{~km}$. south of the present shoreline.

BALL, MAHLON M., SHINN, EUGENE A., AND STOCKMAN, KENNETH W., Shell Development Company (A Division of Shell Oil Company) Exploration and Production Research Division, Houston, Texas

\section{Geologic Record of Hurricanes}

The passage of Hurricane Donna (September 9-10, 1960) across south Florida, an area where details of the pre-storm sea floor were well known, enabled the recognition of widespread storm effects. The recognition of these storm effects led to the conclusion that a significant part of marine sedimentation records the geologic work of large storms.

Specific storm effects were as follows: (1) formation of large quantities of boulder-size rubble by the action of surf on corals at the platform edge; (2) transportation of all sizes of material away from the open sea toward the platform interior; (3) stranding of layers of carbonate mud over wide areas on the supratidal flat (above the normal high tide line).

The amount of boulder-size rubble former by hurricane surf on platform-edge reefs far exceeds the amount produced by day-to-day processes of death and deterioration. Each large storm adds an increment to the building of the rubble accumulations.

The large extent of supratidal flats is due to the ability of storm tides to strand sediment over large areas, the inaccessibility of the supratidal flats to processes that could rework its sediment into adjacent marine environments, and the supply of the supratidal flat sediments at the expense of adjacent marine sediments that compete with it for a place in the geologic record. These factors help explain the large amount of supratidal sediments in some ancient rocks.

Interesting negative aspects of hurricane's effects were that: (1) mound-type accumulations of muddy sediment were not eroded by storm wave or tidal currents, and (2) the sediment-laden waters resulting from the stirring of bottom sediments into suspension by the storm waves and currents did not give rise to effective turbidity currents.

BANDY, ORVILLE L., Allan Hancock Foundation, University of Southern California, Los Angeles, California

Foraminiferal Biofacies in Sediments of the Gulf of Batabano, Cuba*

The Gulf of Batabano is about 180 miles long, 190 miles wide, and is located on the southwest coast of Cuba. The floor of the Gulf is a shallow submerged platform area with water depths ranging between 0 and 40 feet. The southern margin of the platform is bounded by a precipitous declivity resulting in deep-water facies on the south being separated from shoals of the platform by a narrow structural trend.

On the platform, foraminiferal abundance and diversity are greatest in the northern and western areas of Batabano Bay. Ostracodes are also most abundant in these areas. Foraminifera are from 10 to more than 50 times as abundant as ostracodes over most of the bay. General biofacies patterns include abundant miliolids in perimeter areas of the bay, an Elphidium facies in the central area of the bay, and an Archaias facies in the southeastern area of the bay. Areas of mud matrix characterize the first two biofacies whereas non-skeletal grains correlate with the Archaias facies.

Detailed and specific dominant foraminiferal faunas include: (1) a brackish Ammonia beccarii tepida assem-

* Publication authorized by Jersey Production Research Company, Tulsa, Oklahoma. 